\title{
アジア開発途上国大都市における 低炭素交通の診断とQOLを用いた治療の手法
}

\author{
中村 一樹 1 -林 良嗣 2 -中村 文彦 3 -福田 敦 $4 \cdot$ 中道 久美子 5 \\ 1 正会員 香川大学助教 工学部安全システム工学科（テ761-2188 香川県高松市林町2217-20) \\ E-mail: knaka@eng.kagawa-u.ac.jp \\ 2フェロー 名古屋大学教授 大学院環境学研究科（广464-8603 名古屋市千種区不老町C1-2 (651)） \\ E-mail: yhayashi@genv.nagoya-u.ac.jp \\ 3 正会員 横浜国立大学教授 大学院都市イノベーション研究院 \\ （厂240-8501 横浜市保土ヶ谷区常盤台79-5） \\ E-mail: f-naka@ynu.ac.jp \\ 4正会員 日本大学教授 理工学部社会交通工学科（ \% 274-8501 千葉県船橋市習志野台7-24-1） \\ E-mail: fukuda.atsushi@nihon-u.ac.jp \\ 5 正会員 東京工業大学助教 大学院理工学研究科（广152-8550 東京都目黒区大岡山2-12-1-I4-12） \\ E-mail: nakamichi@ide.titech.ac.jp
}

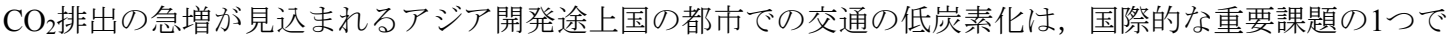
あるが，その実現において都市の経済や社会の利益を損なわない持続可能な開発が必要が急務である。し かし, 大きく社会経済が変化する大都市において, 長期的将来の低炭素交通システムを設計するには, 従 来の予測分析手法の適用は限界がある。本研究では, アジア開発途上国大都市において2050年の低炭素交 通システムをAVOID, SHIFT, IMPROVEの戦略で設計するために, それぞれの戦略の重要性を診断し, 低炭素交通システムのビジョニングから生活の質（QOL）の分析を用いた施策評価までを治療として行う 手法を提示する.
\end{abstract}

Key Words : Asian developing megacities, low-carbon transport strategy, Quality of Life

\section{1. はじめに}

経済成長に伴い $\mathrm{CO}_{2}$ 排出の急増が見込まれるアジア開 発途上国において，全排出量の約 20\%を占める交通部門 の低炭素化は国際的に極めて重要な課題である. その対 策として，不必要な交通需要の抑制（AVOID），低炭 素交通モードへの利用転換（SHIFT），交通エネルギー 消費効率の改善（IMPROVE）の各戦略によるアプロー チが提案されている 1),2). これらの戦略の実施効果は, 国土や都市の空間構成や交通システムの開発経路に依存 する ${ }^{3}$. 多くのアジア開発途上国の大都市では，成長初 期の短期的な渋滞解消対策として道路整備を優先してき たため, モータリゼーションが急速に進行した．近年， 都市鉄道を中心とした大量輸送機関整備が進められてい るが，一度自動車依存型の開発が行われると自動車キャ プティブ層が増加し, 大量輸送機関への転換が進まない ため, この転換をどのように図るかが課題となっている.
加えて, 国連気候変動枠組条約（UNFCCC）に代表さ れる国際的な取り組みでも，交通部門の対策は他部門に 比べ非常に遅れている. 国際的に先進国から途上国一 $\mathrm{CO}_{2}$ 排出削減の事業への資金・技術援助を促すクリーン 開発メカニズム (CDM) では，全事業における交通部 門の事業の割合はたった $0.3 \%$ ある ${ }^{4}$. これは，削減行 動の透明性・正確性を担保する測定・報告・検証の観点 から見た場合, 交通起源 $\mathrm{CO}_{2}$ 排出は交通需要により大き く変動するため実施が難しく, 交通需要の誘導を伴う AVOID や SHIFT を目的とした都市開発事業が採択され にくいためである. 特に, 途上国では需要予測に必要な 詳細データが不足していることに加え, 急速な社会経済 の変化を現在のデータのみで加味するには限界がある. さらに，他部門も含めた国際市場で扱われる炭素価格は 過小評価されており, 従来の交通事業の費用便益分析の 枠組みでは低炭素交通事業の実現は困難である.

一方で, 近年進んでいる国際的な取り組みとして, 国 
別緩和行動（NAMA）では，低炭素化に伴う Co-Benefit を重視して各途上国が必要としている政策を提示する仕 組み作りが進められている。一般的に，途上国では環境 の優先度が高くないが，経済・社会面での Co-Benefit を 考慮した NAMA では交通部門の事業割合が 19\%と関心 が高い4)。交通資金支援メカニズムも，CDM から NAMA を中心としたものへ移行しつつあり，途上国の AVOID や SHIFT を含めた低炭素交通事業への需要は今 後高まると予想される.

これらの取り組みを実現するため，アジア低炭素社会 を長期的に実現しうる交通システム及び都市像を提示す るとともに，そこにリープフロッグ的に至るための施策 群を，バックキャスティングアプローチとして提案する 手法が提案されてきた 5),0,7). このアプローチでは, 従来 の短期的将来における実現可能なシステムの予測（フォ アキャスティング）よりも，長期的将来において実現す ベきシステムの提示をそのビジョニングから行うことを 重視している.この分析では，現在のシステムからの大 きな転換を伴うビジョンを対象とすることが特徴的であ る.このため, そのシステム評価では，その実現可能性 を検証することより，従来分析では固定されてきた社会 経済特性や行動規範をより柔軟に変化させることで実現 しうるシステムの幅を特定することが求められる. しか し，その評価対象は $\mathrm{CO}_{2}$ に限られ，Co-benefit の評価を 含めた包括的な手法は，未だ構築されていない.

本研究は，Co-benefit を考慮したアジア途上国大都市 の低炭素交通システムの実現手法として，現状を踏まえ た 2050 年における具体的なビジョンの提示と, その実 現に向けた施策ロードマップを $\mathrm{CO}_{2}$ と生活の質 (QOL) の観点から検証する手法を提案することを目的とする. 低炭素交通や QOL についてはそれぞれ様々な個別分析 がされているが，低炭素交通システムを実現する手法と して体系化されていない. 特に, 経済成長が進むアジア 途上国都市において低炭素交通を実現するのは容易では ないため，これらの個別分析を組み合わせた俯瞰的な実 現手法を提示することが重要となる。本研究では，この ような手法の構成として, AVOID, SHIFT, IMPROVE の各戦略について, 経済成長著しいアジア途上国大都市 の $\mathrm{CO}_{2}$ 排出構造の診断を利用可能なデータを用いて行い,

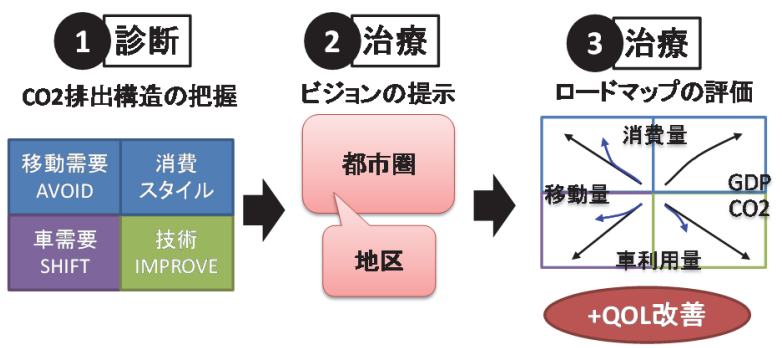

図-1 研究のアプローチ
QOL 分析を用いたアジアの低炭素交通システム構築の ための治療へと繋げる（図-1）。まず，診断では，アジ アの経済成長と $\mathrm{CO}_{2}$ 排出構造について，アジア途上国都 市の現状を日本の都市の過去のトレンドと比較すること でそその欠点 (病状) を特定する. 続いて, 治療では, バックキャスティングアプローチに沿って，低炭素交通 システムのビジョニングと，その実現のための施策ロー ドマップについて，低炭素性に加え住民の価值観に基づ いた QOL 指標を用いた評価を行う。本研究では, この 手法のバンコクへの適用を例示するが，低炭素交通の診 断手法，提示するビジョンの内容，実現施策の評価手法 は，他のアジア途上国都市にも適用可能なものとなって いる．ただし，財政・制度面を含めた施策の実現可能性 の検証については, 本研究の対象外とする.

\section{2. 都市交通起源 $\mathrm{CO}_{2}$ 排出構造の診断}

データの限られたアジア途上国都市において, 低炭素 交通実現に向けた現状診断を簡易に行うことが重要であ る.これについて，1）経済成長に伴う生産・消費需要 の増加，2）生産・消費需要増に対する移動需要の増加, 3）移動需要増に対する $\mathrm{CO}_{2}$ 排出量の多い自動車利用需 要の増加, 4) 自動車需要増に対する交通起源 $\mathrm{CO}_{2}$ 排出 量の増加の関係を 4 象限の図（排出構造四象限図）で示 す手法を提案する. この手法では, 第一象限（右上）に GDP に対する生産・消費需要者の増加, 第二象限（左 上）に生産・消費需要量に対する移動距離，第三象限 （左下）に移動距離に対する自動車走行距離，第四象限 （右下）に自動車走行距離に対する交通起源 $\mathrm{CO}_{2}$ 排出量 の傾きを示す．第二象限から第四象限までで，AVOID， SHIFT, IMPROVE それぞれの重要度を把握することが でき，都市内交通と都市間交通に同様に適用できる ${ }^{8)}$.

この手法による都市内交通起源 $\mathrm{CO}_{2}$ 排出構造の診断で は，経済発展段階（GDP），移動数（トリップ数），移 動距離（トリップ人キロ）, 自動車移動距離（自動車走 行台キロ），交通起源 $\mathrm{CO}_{2}$ 排出量といった主要指標で, それぞれの関係を 4象限の図で示す. これらのデータは パーソントリップ調査や陸運統計等から収集する. 全て の交通機関の移動距離の情報が同様に整備されている訳 ではないが，各種の情報を組み合わせることで積み上げ 式に推計することはできる.さらに，これらは交通の動 向を示す最も一般的な指標であるため, 途上国大都市で も個別調查等から推計することも可能である.

この手法を用いて，アジア途上国大都市で発展中期に あるバンコクと，人口レベルが同規模のアジア先進国都 市の東京において，それぞれの $\mathrm{CO}_{2}$ 排出構造の特徵を比 較分析した. バンコク大都市圈と東京都のデータを用い 


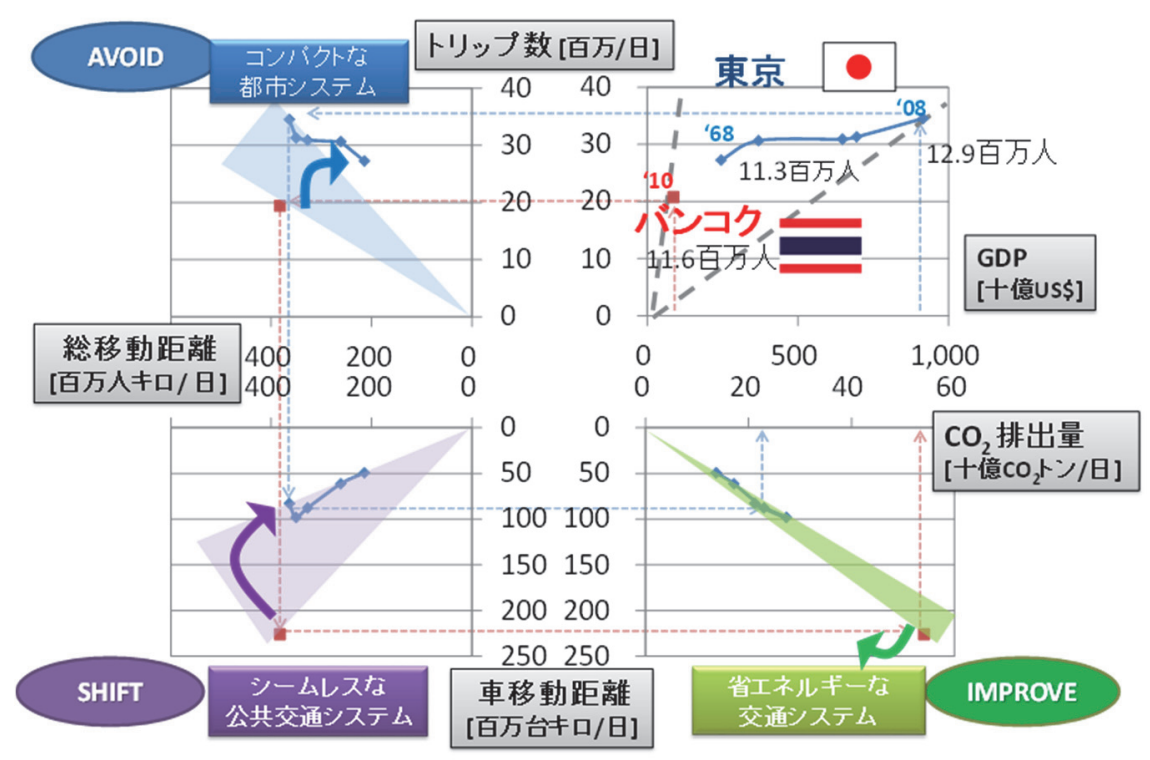

図-2 都市内交通起源 $\mathrm{CO}_{2}$ 排出構造の四象限図

て 4 象限の図を描いた結果（図-2），トリップ当たりの 移動距離と移動距離当たりの自動車移動距離が，2008 年の東京ではそれぞれ $10.5 \mathrm{~km}$ と 0.23 であるのに対し, 2010 年のバンコクでは $18.4 \mathrm{~km}$ と 0.59 と大きいことが示 された。 また，バンコクの GDP はまだ東京の $1 / 10$ 程度 であるにも関わらず，移動距離と車移動距離はほぼ同等 で, $\mathrm{CO}_{2}$ 排出量は約 2.5 倍と, 非常に高炭素な都市交通 システムになっていることが分かった.

一方で, 自動車移動距離に対する $\mathrm{CO}_{2}$ 排出量は, バン コクと東京は同程度であった。 これは, 乗用車に比べエ ネルギー効率が高い二輪車利用がバンコクでより多いこ とに起因すると考えられるが，今後のモータリゼーショ ンの進行により, 乗用車への転換が進み, 交通エネルギ 一消費の効率も悪化することも予想される.

\section{3. 低炭素交通システムのビジョン}

$\mathrm{CO}_{2}$ 排出構造の診断から分かるように, アジア途上国 大都市における交通システムの将来ビジョンは, 都市域 の拡大と乗用車利用の増大を抑制するものであることが 重要である.このため, アジア途上国大都市に対してよ り一般的な将来ビジョンを検討し, 定性的な提案を行っ た. 将来ビジョンとは，現状と想定される将来変化を組 み合わせて長期的将来のあり方を示寸ものであり，社会 的背景に関する理念的な社会ビジョンと，それを支える 物理的な交通システムのビジョンとに分けられる ${ }^{4}$. 前 者の社会ビジョンは, 人口・経済の変化といった将来起 こるであろうと想定されるマクロな背景としてより固定 されたシナリオである一方, 後者の交通システムビジョ ンは, 都市・交通政策により操作可能なシナリオとして
基本的に区別する．本研究では，アジア途上国都市の低 炭素交通システムの将来ビジョンを, 都市空間構造の改 変による AVOID, 交通ネットワークとモード階層の形 成による SHIFT, 交通モード別の技術革新による IMPROVEの戦略の組み合わせて提示寸る.

一方で，これらのビジョンで対象とするシステムは相 互影響する部分もあり, 交通システムがライフスタイル のような社会システムの一部に影響を及ぼすとも考えら れる. しかし, 本研究で示寸ビジョンは, 長期的将来に おいて低炭素交通のために実現すべきシステムを規範的 に示すもので，その実現プロセスにおける各システムの 相互影響を通した変化を予測するものではない，本研究 では，都市の交通ビジョンによらない上位レベルの社会 ビジョンを設定するために，ライフスタイル変化による 価值観の変化をより一般的な要素を用いた QOL で表す.

\section{(1) 社会ビジョン}

アジア途上国では，2050 年までに 1 人当たり GDP は 数倍に増加していくが, 2030 年頃から高齢化による人 口減少が顕著になると予測されている 9. この背景を踏 まえ, 本研究では, 経済的な効率性を追求した積極的な 成長を遂げる発展初期から，徐々に社会的な充足性を探 求する緩やかな成長を目指寸発展成熟期へと向からこと を想定する.これは, 生産スタイルとしては大量生産・ 消費から地産地消へ, ライフスタイルとして労㗢重視か ら社会活動重視へと産業構造や価值観が変化することを 意味する. 交通においては, 現在でも生産年類層と高齢 層の交通目的の違いに見られるように，通勤交通から私 用交通が増加していくことが考えられる.これらの変化 は, 先進国の成長期から成熟期にかけて共通して見られ る傾向であり, 途上国においても将来起こるであろう一 
般的な社会ビジョンと考えられる.

このようなライフスタイルの変化に伴い，交通機関や 居住環境に関する価值観も変化することは考えられる.

価值観変化の一意的な将来変化の想定は困難だが，これ らの価值観をより一般的な構成要素で定量的に把握する ことで，様々な都市・交通システムの形態による居住環 境・交通機関への選好の違いを属性別に表寸ことが出来 る QOL 指標が構築されてきた ${ }^{10)}$. QOL 分析において, 価值観は欲求の充足度と関連があり, 欲求の段階応じた 価值観の変化の傾向が見られるとされている. 現在の途 上国大都市の住民の属性間の違いは大きいから，所得層 や年齢層別に価值観の違いを比較することは，その変化 の傾向を把握する上で有用である. 本研究では, このよ うな価值観の違いを QOL 分析で把握し, 属性構成変化 に伴う価值観変化を表現した。

\section{(2) 交通システムのビジョン (都市圏)}

このような社会像の想定から, 将来の交通システムに 求められるものは, 需要追随型の量的な空間設計から, 多様な需要に対応する高質な空間設計へと転換すること であると考える.アジア途上国都市における急速なモー タリゼーション・都市スプロールは, 自動車依存社会を 形成することにより, 過度な渋滞を発生させアクセシビ リティを低下させだけでなく, 将来の高齢化社会におけ るモビリティの確保をも難しくする．しかし，経済成長 初期では，交通モビリティの改善が経済成長を大きく支 え, 成熟期においても社会生活でモビリティは重要であ るため, 交通需要の抑制（AVOID）には限界がある.

このため, 旅客交通については, 交通機関の転換
（SHIFT）を軸とし，都市内の公共交通システムを整 備・改善することが必要となる。このような公共交通シ ステムは, 将来の多様な移動需要の増加に適用可能であ るため, 高質な都市インフラのストックとして構築する 必要もある。これらは, AVOID を軽視しているわけで はなく, AVOID を実現のための都市拠点を形成するた めにも, 公共交通整備による開発軸の形成が必要である ことを示している ${ }^{3)}$.

これらを踏まえ, アジアの低炭素都市・交通システム のビジョンとして, 技術革新に加え, 高性能な大量輸送 機関（MRT: Mass Rapid Transit）が端末交通と連携したシ ームレスな公共交通システムを軸にし，都市の規模に応 じて，その拠点駅周辺に駅と接続性の高い魅力的な居住 地開発と, 郊外拠点駅を含めて都市中心機能の多極展開 をしていくことが必要であると考える（図-3）。ここで, アジア途上国で既に普及している公共交通には，オンデ マンド型や路線型といったサービス形態や，二輪車から バスといった車両形態で，様々な機関が存在する．これ らの交通機関は経済成長により衰退するものもあるかも しれないが，コミュニティベースの端末交通として活用 することが望ましいと考える.

アジア途上国都市におけるビジョンの実現施策に重要 なのは, MRT の整備時期と, その輸送機関性能の選定 である．都市鉄道の整備可能時期は経済レベルや人口規 模で主に決定されるが 11), 整備有郊時期は都市域拡散度 や車依存度で決定される )。 また, 大量輸送機関は鉄道 だけでなく, LRT, BRT (Bus Rapid Transit), 普通バス と複数あるが, その有効な輸送力は現在だけでなく将来 の都市成長も踏まえて判断しなくてはならない.これに

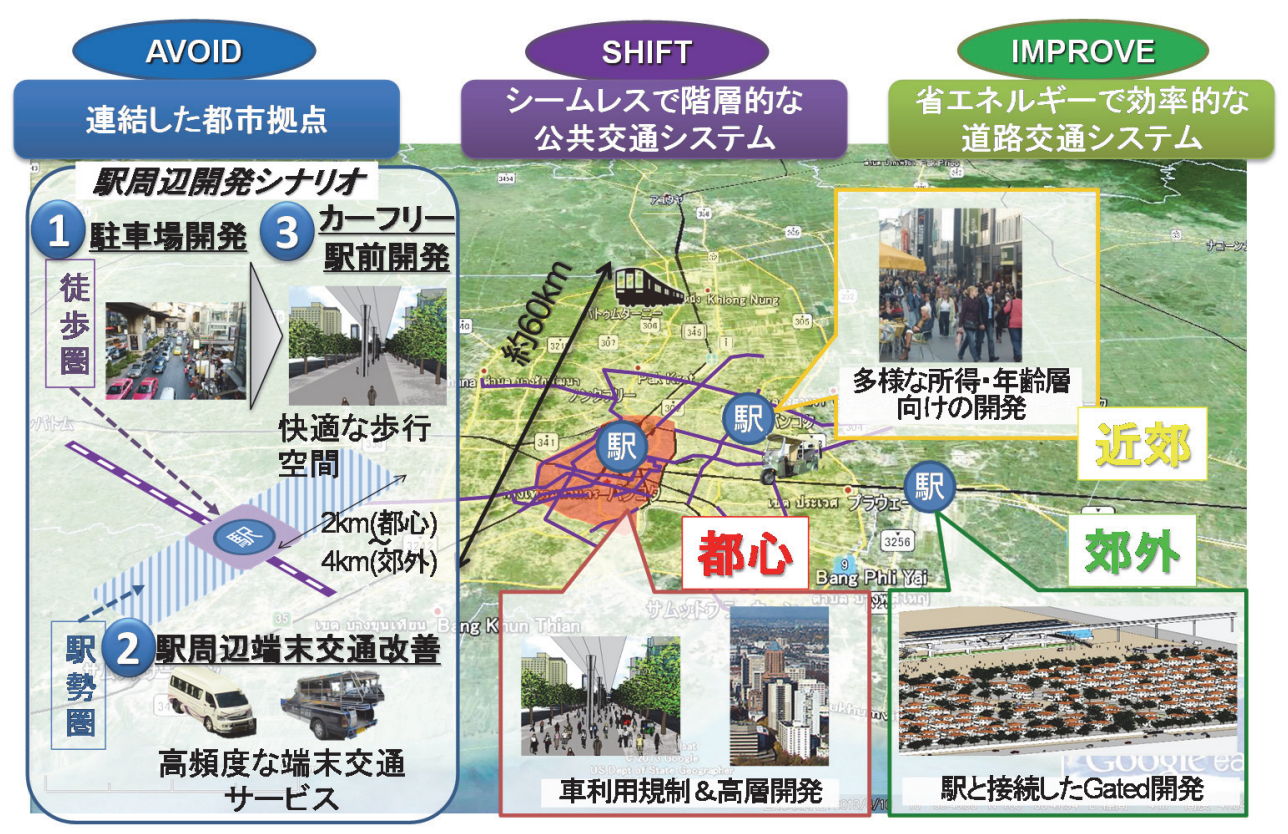

図-3 都市内交通ビジョン 
つい, モータリゼーションが進むアジア途上国大都市 でも，早期に MRT 整備を行えば鉄道が最も低炭素とな るだけの需要を確保できると示されている ${ }^{12)}$.

\section{(3) 交通システムのビジョン（地区）}

上記の都市圈スケールの交通システムのビジョンのみ では，アジア途上国大都市での実現は容易ではない。こ れを支える地区スケールの交通システムのビジョンとし て，都心，近郊（都心地区の外縁部）, 郊外（市街化さ れた都市域の辺縁部）それぞれで, 駅周辺開発のシナリ 才を検討する必要がある.

道路優先整備によるモータリゼーション進行により都 市域が拡散したアジア途上国大都市では，車利用が習慣 化しているだけでなく, 既存市街地に駅が設置されるた め, 計画的な TOD（Transit Oriented Development）を実施 することが困難となる．近年のアジア途上国大都市では MRT が整備され始め，都心の駅周辺に民間の高層開発 が進んでいる.このような開発は，MRT を利用する中 所得層の居住を増やす一方で，車依存の高所得層も多く 居住する傾向にあり ${ }^{13)}$ ，駅周辺開発が MRT 利用に繋が らないという問題が生じている.

このため，比較的地価の安く新規開発が可能な都心の 駅間の地区や郊外においては，都心の中・低所得層や郊 外の中所得層の公共交通利用を促進するため, TOD の 促進と端末交通の充実が必要となる。また，車依存の高 い郊外地区では，郊外と都心を結ぶ鉄道を高速化し，駅 と居住地区を, カーシェア, 自転車シェア, 電動オート バイシェア等を活用した端末交通で駅と結ぶことで，そ の利便性を確保することも重要である。ここでは,

Gated 開発地区の片側の門を道路側に設けつつ, 反対側 の門を駅へのアクセスポイントにするようなデザインの 工夫もビジョンの要素として考えられる.

さらに，軌道系を軸とした都市への変革をより確実な ものにするためには，都心側での徹底した歩行者優先， とそれに連携した公共交通政策等を加えるというシナリ オも, リープフロッグなアプローチとして検討する必要 がある. 都心では路線密度が高く駅勢圏は小さくなるた め，歩行空間化に適している．都心歩行空間化は，短期 的には周辺道路の混雑悪化を招く可能性もあるが，長期 的なライフスタイルや交通行動の転換を促すインパクト をもたらすためには有郊なオプションであると考える. 本研究では, より大胆に都心から車を排除し徒歩圈での 活動を促進するカーフリーシナリオも提案に含める.

\section{4. 低炭素化ロードマップの評価}

提示した低炭素交通システムのビジョンを実現するた
めに，そのロードマップの定量的な評価を行う．本研究 では, その手法として QOL 分析と都市モデルによるシ ミュレーション分析を用いる. 本章では, 各手法のアジ ア途上国都市への適用において工夫した点と, 得られた 結果について述べる.

\section{(1) QOL分析}

低炭素交通システムの利用を普及させるためには，低 炭素だけでなく，その利用によって生活の質を上げるも のでなければいけない. QOL 指標を用いることで，車 利用と鉄道利用から得られる生活の質の違いを比較し， 鉄道利用普及に求められる鉄道システムや駅周辺の環境 の質の改善の効果について検討することが可能となる.

そこで QOL について，交通機関と居住環境の質に分け， それぞれの構成要素に対するアジア都市の住民の価值観 を属性別に分析した $\left.{ }^{14)}, 15\right)$ (図-4）。

交通機関と居住環境の質に関する QOL 指標は，それ ぞれを構成する要素項目の水準を，その重要度と掛け合 した線形関数で定量化する ${ }^{19}$. 交通機関と居住環境の質 の要素項目は，それぞれ利便性・快適性・安全性で整理 した. 居住環境の利便性はアクセスを示すものとし，こ の各項目を交通機関の質の指標で示すことで, 最終的な QOL 指標は居住環境の質に統合する. 要素項目の水準 は，時間（分）と大きさ $\left(\mathrm{m}^{2}\right)$ に関する指標は定量的 な単位で示し，その他の項目は良し悪しのダミーで示寸． アクセスに関する指標は, 時間 (分) とコスト (バーツ) を統合した一般化費用（分）で算出する.

\section{a) アンケート調査}

本研究では, バンコクを対象に街頭アンケート調査を 行い, 属性別の重要度のパラメータを推計した. アンケ 一ト調査は, 交通手段選択と居住地選択における魅力要 素への重要度に関する SP（Stated Preference : 表明選好） データを集めるようコンジョイント分析で設計した. 聞 き取りにおける質問は，交通機関・居住環境それぞれの 質の要素項目について，良し悪しの水準を組み合わせた

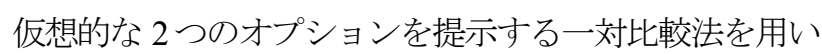
た. 定量的な項目の水準值の良し悪しは, バンコクの現 地状況を踏まえて設定した.

聞き取り調查は，2012 年 11〜 12 月に行い，合計 1080 人を対象としたサンプルを収集した．また，属性による 価值観の違いを把握するため, パラメータ推定は, 所得 や年齢の違いによって行った. 所得は，1 ケ月当たりの 世帯収入が 2 万バーツ以下の人を低所得層, 10 万バー ツより多い人を高所得層, それ以外を中所得層とする. 中所得層については年齢による分析も行い，60 歳以上 を高年層とし，それ以外の若中年層とで分類した.

このデータを用いて, 属性別に各要素項目の水準值の 良し悪しに対する重要度パラメータを, 2 項ロジットモ 


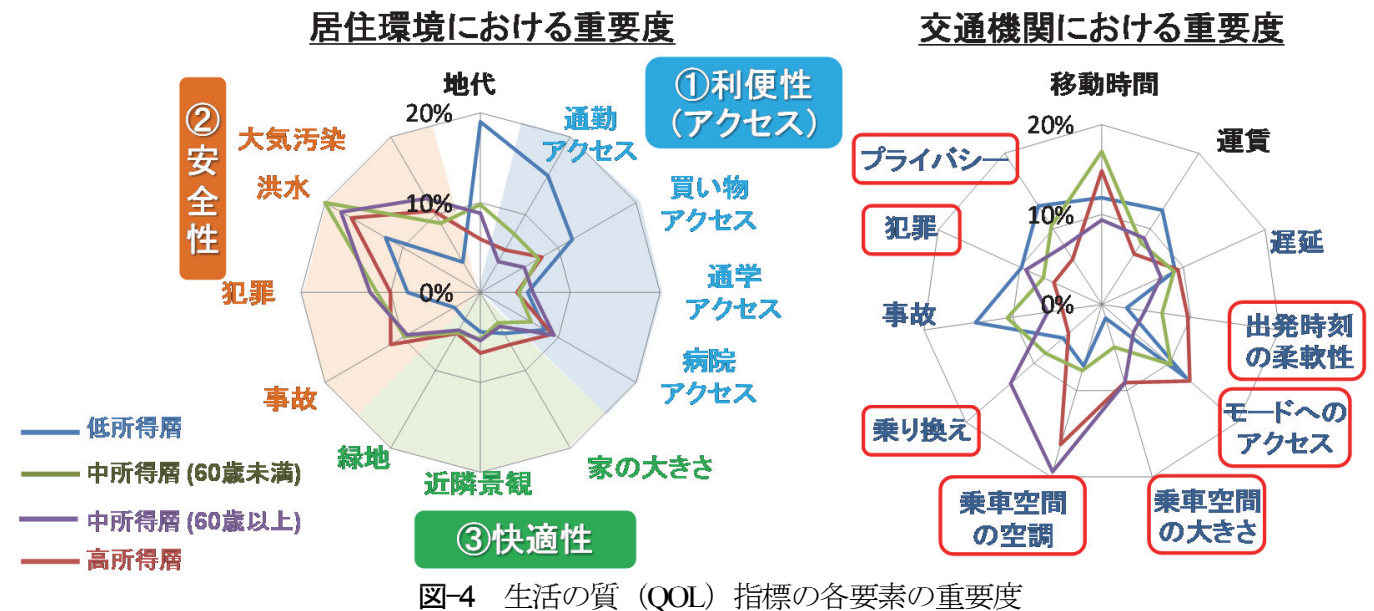

デルに基づき最尤推定法で推計した．この結果，尤度比 は全ての分析で 0.2 以上, 各重要度の $\mathrm{t}$ 值は 2 以上と, 有意な結果が得られた。 図-4 は, 属性による重要度の 違いを明確にするため, 全ての重要度の值を属性毎に足 して 100\%になるよう相対值で示したものである.

\section{b) 交通機関と居住環境への価値観}

交通機関については，低所得層は移動コストと安全性， 中所得層は移動時間, 高・中所得高齢層では移動の快適 性をそれぞれ重視していることが分かった．これは，高 所得層や高齢者層が所得や年齢に伴いモビリティを高め ていくプロセスの中で，移動快適性の高い乗用車利用を 選好していくという従来のモビリティ進展のパスを示し ている。，一方で，交通渋滞の影響が少なく事故率も低い 鉄道利用は，移動時間と安全性において利点があり， 中・低所得層にとってより魅力的であることも示されて いる．ただし，これは駅周辺間の移動を行う場合であっ て，バンコクでもまだ鉄道路線が限定的でネットワーク として十分に整備・機能しておらず，端末交通として利 用される二輪タクシ一等も十分に安全とはいえない。こ のように，乗用車の質は快適性において利点があるが， 都市鉄道の質は利便性・快適性・安全性それぞれについ て改善の余地があると考えられる.

また，居住環境への価值観については，低所得層は居 住コストとアクセス性を重視しているのに対し，中所得 層と高所得層は居住の安全性をより重視していることが 示された．中・高所得層を比較すると，中所得若中年層 に比べ，高所得層や高齢層がより快適性を重視する傾向 にある，これは，乗用車利用の選好が高くなると，安全 性や快適性の高い郊外の Gated 開発地区に居住するライ フスタイルを好むことを表していると考えられる。一方 で，アジア途上国大都市において，このような高級住宅 開発は都市鉄道の駅周辺でも進んでおり，ここでも車利 用を中心とした高所得層の居住が増えている.この結果， 公共交通利用がより必要な低所得層が, 駅周辺に居住す
ることが難しくなる．このため，鉄道駅周辺の居住と鉄 道利用を共に促進するような開発を行うことが重要とな る.これらのことから, 鉄道整備において, 駅周辺に安 全性・利便性・快適性の高い高質な居住空間を整備する と同時に，駐車場開発といった車利用の規制を行い，駅 周辺居住による鉄道利用を中心とする新たなライフスタ イルをより幅広い層に提供する必要があると考えられる.

\section{(2) シミュレーション分析}

属性別の価值観を踏まえて，交通システムのビジョン 実現の低炭素化ロードマップと，QOL 改善における有 効性を検証した. 本研究では, 都市の空間構造を考慮し て 2050 年までの都市内交通起源 $\mathrm{CO}_{2}$ 排出量推計を行う

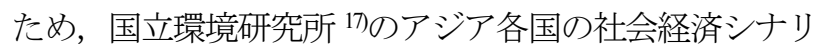
オ，アジア途上国大都市における長期的な乗用車保有率 の推計值と車両技術進歩シナリオ 7を用いて，バンコク 都市圈の土地利用交通モデルの構築を行った ${ }^{18)}$ （図-5）.

\section{a) 都市モデル}

近年の土地利用交通モデルの開発は，より詳細な空間 スケールで多様な行動を表すようなマイクロシミュレー ションが主だが，データが十分に整備されていないアジ ア途上国でこれを適用するにはまだ多くの課題がある. そこで，本研究では，より単純な初期の土地利用モデル として集計的な空間相互作用モデル（Spatial Interation） を構築し ${ }^{19}$ ，交通モデルとして 4 段階推計法を適用した. 本モデルは，2005年を初期值として 5 年周期でシミュレ ーションを行い，2050年のアウトプットを推計する.

本モデルの特徵として, 交通機関と居住環境の質の変 化による QOL の変化を，交通手段選択・居住立地選択 モデルに内生化することで，生活の質の変化による交 通・居住行動の変化を表現する. 属性 $s$ 別の交通機関 $m$ の選択と居住地 $i$ の選択の効用 $V t_{s, n} V_{s i}$ を, 交通一般化 費用 $g c_{m}$ や人口規模 $p o p_{i}$ と, 従来モデルの定数項を変数 にした QOL 指標值で説明した. 効用に対する违減パラ 


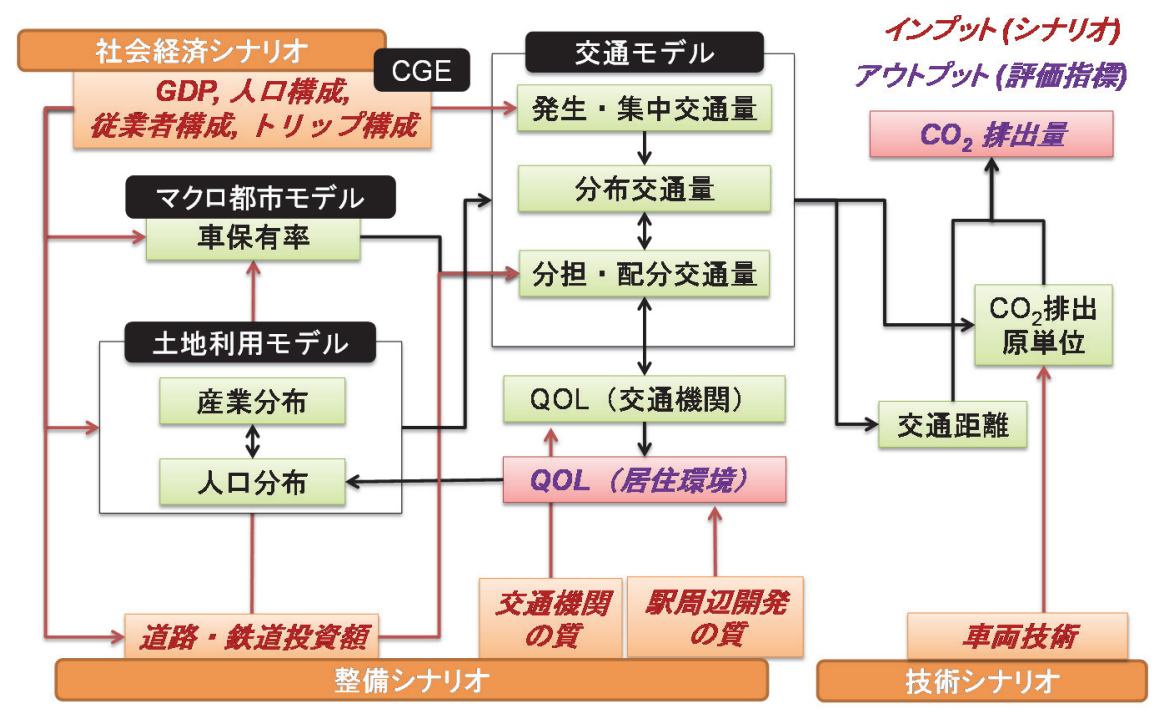

図-5＼cjkstart都市モデルのフレームワーク

メータ $\theta_{1}, \theta_{2}$ は, QOL 分析から得た。交通機関の質を表 寸 QOL $t_{s m}$ は，車は図-4 の赤枠の要素項目を高い水準に 設定した．一方で，鉄道は端末交通を改善することで， その高質化を図ることを想定する，居住環境の質を表す $Q O L l_{s i}$ は，鉄道整備に伴う高質な駅周辺開発として快適 性の要素項目（家の大きさ・近隣景観）を高い水準に設 定した.

$$
\begin{aligned}
& V t_{s, m}=\exp \left(\theta_{1} \cdot\left(g c_{m}-Q O L t_{s, m}\right)+\lambda_{1} \cdot \text { Car }_{s}\right) \\
& V l_{s, i}=\exp \left(\theta_{2} \cdot\left(\text { OOLl }_{s, i}-\text { rent }_{i}\right)+\ln \left(\text { pop }_{i}\right)\right)
\end{aligned}
$$

また，予測モデルの妥当性を確保するためには，行動 モデルと QOL 分析のパラメータは同時推計等でその整 合性を検証する必要がある。しかし，途上国都市では， データ取得の労力が高いことに加え, 長期的に大きく変 化すると想定される行動変化を現在の顕在化した行動分 析でモデル化するには限界があると考えられる. 本モデ ルでは，短期的な予測モデルとしての精度を高めるので はなく, 長期的な行動変化の幅を潜在的な選好を表す QOLを用いてより柔軟に表現することを重視した。

しかし，QOL は潜在的な選好を示すもので，行動の 制約や習慣は表現できない 20)。そこで，利用可能なデー タからモデルの現況再現性を確保するよう，各行動の定 数項のパラメータを調整した. バンコクの既往調査の都

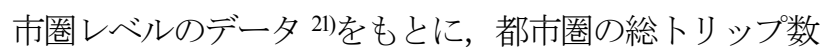
データから推計した地区別の総出発トリップ数と総流入 トリップ数，都市圏の総自動車移動距離と，各交通機関 の分担率のデータに整合するよう，各行動の定数項を調 整して決定した.
さらに，算出された行動モデルの定数項のパラメータ は将来シミュレーションでは可変であると設定し，長期 的な行動変化をより柔軟に表現した．特に，乗用車保有 が交通行動に与える影響を考慮した。乗用車保有率デー タを QOL 調査で収集した結果，低所得層の世帯車保有 率は $15 \%$ であるのに対し，高所得層は $80 \%$ と，各属性で 大きく差が見られ，これが各属性の車利用に大きく反映 していることが分かった。このため，交通機関選択モデ ルにおける属性別の鉄道利用の定数項パラメータは，車 依存度を表す変数として乗用車保有率 $\mathrm{Car}_{s}$ と関連付け ることで車依存の影響を表した ${ }^{13)}$. 居住立地選択モデル における地区別の定数項パラメータについても，地価を 表す変数 rent $t_{i}$ して属性別の地区居住者の QOL の期待 効用関数と関連付けることで 2), 地価の影響を間接的に 内生化した.

\section{b) 将来シナリオ}

将来のシミュレーションにおいては，経済成長や高 齢化で属性の内訳が大きく変わることで，長期的な交通 需要の変化を表現した．社会経済シナリオについては, バンコクでは， 60 歳以上の高齢層は 2005 年の $10 \%$ から, 2050 年には $25 \%$ になとされている. また，2005 年に は，低所得層と高所得層の割合はそれぞれ 51\%，4\%と なっているが，本研究のシナリオでは，2050 年にはそ れぞれ 19\%，27\%まで変化するとした。 トリップ数につ

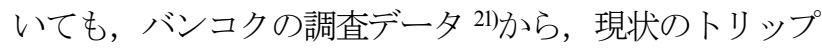
目的の内訳をインプットし, 既往研究 ${ }^{23)}$ の将来予測のデ 一タを参考に私的交通が増えるようシナリオ化した。

低炭素交通システムの整備シナリオについては，3の ビジョンに基づき設定をした。このようなビジョンを実 現するためのロードマップは，都市の特性により異なる. 特に, 鉄道整備が可能な発展段階に達していない都市で 
は，まずバスを中心とした公共交通システムを構築する 必要がある. 一方で，モータリゼーション・都市スプロ 一ルが急速に進む都市では，十分な需要の転換を実現す るために大規模な鉄道網の構築を早期に行う必要がある。

バンコクは経済・人口面で鉄道整備は可能な発展段階 にあり，モータリゼーションは進行しているものの， 2030 年までに現行の鉄道整備計画が進めば最も低炭素 であるとされている ${ }^{12)}$. そこで, 本研究では, バンコク で計画される約 $500 \mathrm{~km}$ の都市鉄道網の整備を 2030 年ま でに行う鉄道優先整備シナリオ 24 , 25)を設定し，その投資 額を道路整備のみに投入する道路優先整備シナリオとを 比較した，道路整備は，道路容量を拡大寸ることで渋滞 を解消する（IMPROVE）ことを期待するが，道路交通 の誘発需要を発生させることでその効果は低下してしま う。一方で，鉄道整備は，道路交通の需要を鉄道へと転 換（SHIFT）することで，道路需要そのものを削減する ことができ，渋滞解消効果へと繋がる ${ }^{20}$.

また，鉄道優先整備シナリオについては，地区スケー ルのビジョンとして駅周辺開発シナリオを更に設定した. ここでは, 駅前に車依存の開発を許容する車中心駅前シ ナリオ，駅の周辺地区への端末交通サービスを改善する 駅周辺端末改善シナリオ, 駅前から車利用を排除するカ ーフリーシナリオについて分析を行った. 本モデルでは, 駅周辺開発シナリオ別に端末交通手段の分担率と人口分 布を駅からの距離帯別に設定し, 端末交通の時間とコス 卜を推計する. 車中心駅前シナリオは BAU を表し, 所 得が高い層がより駅近くに立地するよう設定した. 駅周 辺端末改善シナリオでは, 端末交通における公共交通運 賃を無料化するケースを想定する. カーフリーシナリオ は, 駅周辺端末改善に加え, 駅から 400m の距離帯にい
る居住者は車利用が出来ないよう設定した.

カーフリーシナリオは, 現段階では実現が困難なもの であるが，本研究では実現可能性は評価の対象外とする. 本研究で示したビジョンの意図は, 低炭素交通のために 実現すべきシステムを示すことである.ここでは，長期 的将来において大幅な $\mathrm{CO}_{2}$ 削減を達成するために, 大胆 な変化をもたらすシナリオとしてカーフリーシナリオを 設定した。 また，QOL 評価は，シナリオに対する地元 住民の潜在的な受容可能性を示寸と解釈でき，長期的な 実現可能性に関係すると考えられる.

\section{c) 整備シナリオの評価}

これらのシナリオの分析結果を, 四象限の図で示寸 (図-6)，道路優先整備を行った場合は, $\mathrm{CO}_{2}$ 削減率は 現況比 9\%にとどまる一方で, 鉄道優先整備の場合は, $\mathrm{CO}_{2}$ 削減率は 2005年比 22〜36\%（図-6 右下）となること が示された. また，道路優先整備に対して鉄道優先整備 は，2005年比の移動距離の増加を 19〜29\%（図-6左下）， 車移動距離の増加を 96〜166\%（図-6 左下）減らすこと が可能であることが分かった. 鉄道優先整備シナリオの 中では, トリップ数に対する輸送距離（AVOID）の傾 き（図-6 左上）よりも, 輸送距離に対する車移動距離 （SHIFT）の傾き（図-6 左下）において違いが見られ， 駅前から車利用を排除寸るカーフリーシナリオで $\mathrm{CO}_{2}$ 削 減が最も高い結果となった。 これは, 道路優先整備シナ リオでは自動車分担率が 76\%となるのに対し, カーフリ ーシナリオでは $23 \%$ の鉄道分担率を実現することで, 自 動車分担率を $48 \%$ まで抑制できることによる.

QOL 改善効果についても, 鉄道優先整備シナリオで は, 2005 年に対して全ての属性の層で駅勢圈の QOL を 向上させる結果となった（図-7）。しかし，車中心駅前

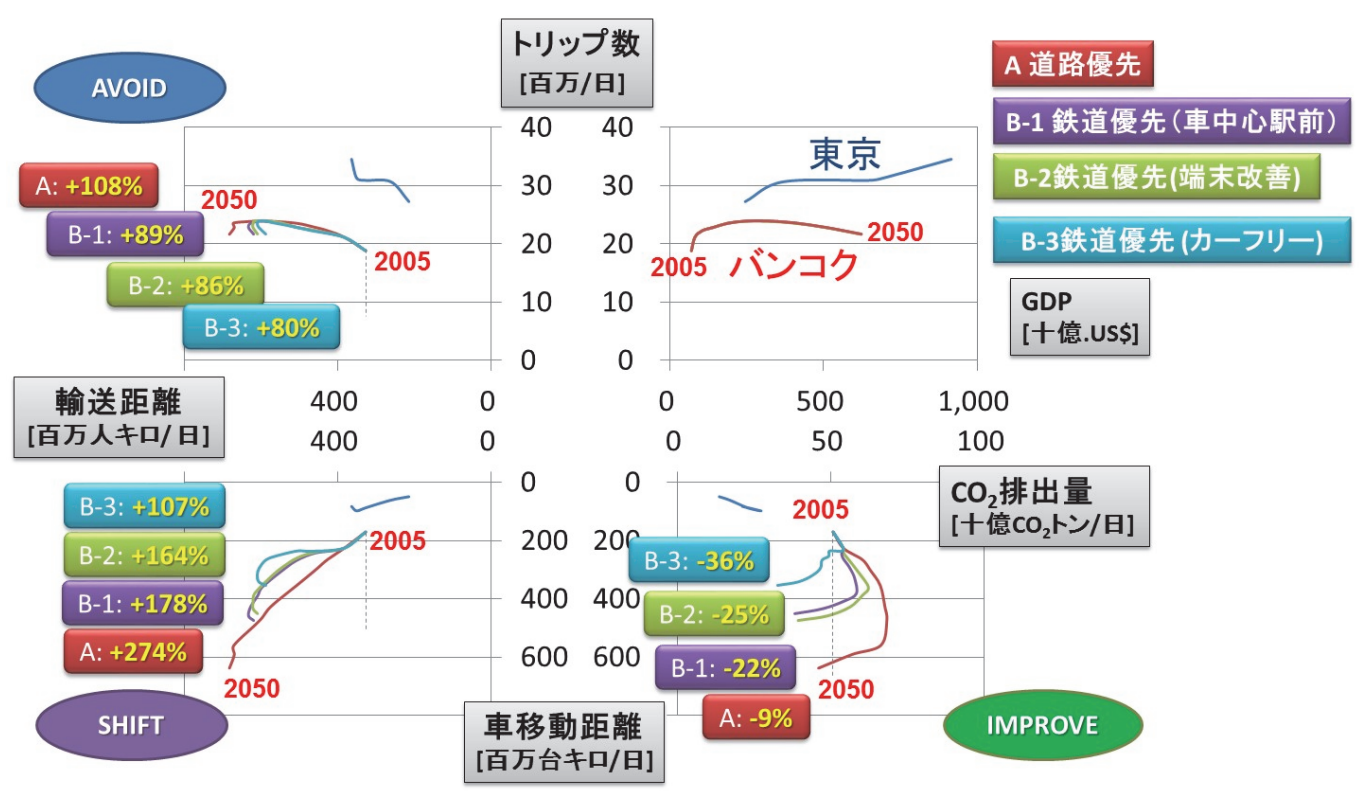

図-6 鉄道優先整備による $\mathrm{CO}_{2}$ 削減効果 


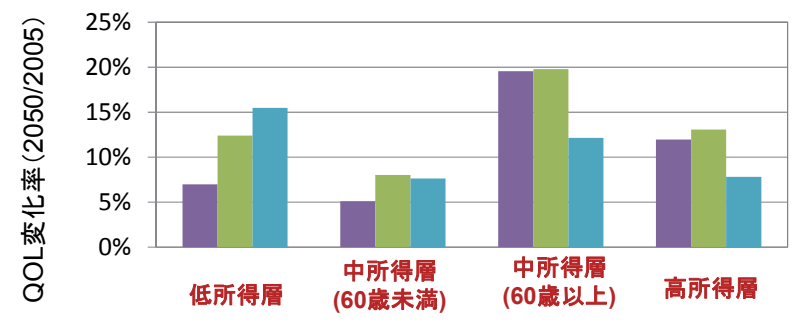

図-7 鉄道優先整備による駅勢圏の QOL 改善効果

開発では，中所得高齢層と高所得層の QOL はより高く 向上し，鉄道利用者である中所得若中年層と低所得層へ の効果が低いことが示されている. これに対し, 駅周辺 の端末交通改善は，これらの鉄道利用者の QOL を車中 心駅前開発より高く向上できる. カーフリーシナリオは, 低所得層の QOL を更に向上させることが可能であるが, 高所得層や中所得高齢層にとっては車利用が制約されう ためQOLが低くなる.

駅勢圈外を含めた全体の QOL 改善効果については, 2005 年からの都市スプロールにより移動距離が増加す るため, 全体的に QOL は低下する.この結果, 中所得 高齢層では 2005 年比 QOL 改善効果は 6〜 8\%となり，低 所得層は-3〜-19\%, 中所得若中年層は-1〜-17\%, 高所得 層は-6〜-7\%と負の効果になる.しかし，道路優先整備 シナリオに比べると, 鉄道優先整備シナリオにおける端 末交通改善とカーフリーの QOL 改善は，低所得層と中 所得若中年層でより効果的である. 一方で，道路優先整 備シナリオは, 高所得層と中所得高齢層でより効果的で, QOL をそれぞれ 2005 年比 17\%と 24\%改善する. これら を踏まえると, QOL 改善の観点から最も効果的な整備 は，低所得層では鉄道優先整備のカーフリーシナリオ， 中所得若中年層では鉄道優先整備の端末交通改善シナリ 才，高所得層と中所得高齢層では道路優先整備シナリオ となる。

\section{5. 結論}

本研究では，アジアの低炭素交通システムの設計手法 を具体化し，現状の診断に基づくビジョンづくりから実 現施策の評価までのプロセスを一貫した分析ツールとし て提示した.アジアの長期的将来における社会経済や都 市開発の変化に伴う交通需要の大きな変化を想定した上 で，生活の質の評価を低炭素交通システムの分析に組み 込み，その実現手法をより多面的に評価することを可能 とした.

この手法を用いて分析した結果，アジア途上国大都市 の都市内交通起源 $\mathrm{CO}_{2}$ 排出構造の診断では，急速なモー
タリゼーションと都市スプロールで移動距離と車利用率 の増大が顕著であり，AVOID・SHIFT 戦略が重要である ことが分かった．また，この戦略を具体化した将来ビジ ヨンとして，経済成長や社会生活を支える MRT 整備 （SHIFT）を中心としたアプローチが必要であり，現状 の車依存を許容する駅周辺開発の改善を含めたビジョン を提示した。

そして，2050 年のビジョン実現の施策ロードマップ を，バンコクをケーススタディに評価したところ，鉄道 優先整備は道路優先整備より低炭素であることが分かっ た. 加えて, 鉄道優先整備における駅周辺開発シナリオ では，カーフリー駅前開発が最も低炭素であることが示 された. 一方, QOL 改善効果については, 鉄道優先整 備は 2005 年より駅勢圈の QOL を向上させ，鉄道利用者 である低所得層と中所得若中年層の QOL を向上するた めには，駅周辺端末改善シナリオやカーフリーシナリオ のような駅周辺開発が道路優先整備より有効であること が分かった.しかし, 道路優先整備は車利用者である高 所得層と高齢層への効果がより高い結果となった. どの シナリオが最も低炭素交通実現に適しているかは， $\mathrm{CO}_{2}$ 削減目標と社会構造により決定されるものと考える.

これらの分析結果の前提として, 将来動向の予測（フ オアキャスティング）ではなく, 将来ビジョンの評価 (バックキャスティング) であるという点に留意する必 要がある. 本分析は, 設定した将来ビジョンの有効性を 議論したものであるが，従来重視されてきた将来予測の 妥当性については検証の限界が生じる，また，新たな提 案であるカーフリー開発によって得られる歩行空間整備 等による QOL の向上は，本分析では考慮できておらず， 更なる手法の改良が求められる. これによって, ビジョ ンをより多様化していくことも重要であろう.

本研究の成果は，アジア途上国都市の低炭素都市交通 実現のための海外支援に携わる際に有用であると考え る. 特に，低炭素都市・交通システムとその実現手法の メニューを, 多様なライフスタイルの価值観を考慮して 提案できることは重要である. このため, アジア途上国 大都市だけでなく，それに続いてモータリゼーションに よる啮滞が深刻化し交通計画，都市計画に関するマスタ 一プランが作成段階である多くのアジア都市において も，その適用が期待される.

謝辞 : 本稿は，環境省・環境研究総合推進費(S-6-5)「ア ジアにおける低炭素交通システム実現方策に関する研究」

(代表 : 林良嗣) の支援により実施された. ここに記し て謝意を表する.

\section{参考文献}

1) Dalkman, H. and Brannigan, C.: Transport and Climate 
Change; Sustainable Transport, A Sourcebook for Policymakers in Developing Cities, GTZ, 2007.

2) 中村英夫，林良嗣，宮本和明（編著）：都市交通と 環境一課題と政策，運輸政策機構，2004.

3) Nakamura, K. and Hayashi, Y.: Strategies and instruments for low-carbon urban transport: an international review on trends and effects, Transport Policy, Vol. 29, pp. 264-274, 2013.

4) Hayashi, Y., Nakamura, K., Ito, K. and Mimuro, A. (eds.): Putting Transport Into Climate Change Agenda; Recommendations from WCTR to COP19, the WCTRS report, 2013.

5) Hickman, R., Ashiru, O. and Banister, D.: Transitions to low-carbon transport futures; strategic conversations from London and Delhi, Journal of Transport Geography, Vol. 19, pp. 1553-1562, 2011.

6) 運輸政策研究機構：低炭素社会における交通体系に 関する研究報告書, 運輸政策研究機構, 2011 .

7) 中村一樹, 林良嗣, 加藤博和, 福田敦, 中村文彦, 花岡伸也：アジア開発途上国都市における低炭素交 通システム実現戦略の導出, 土木計画学論文集 D3, Vol.68, pp.I_857-866, 2012.

8) 林良嗣：貨物高速鉄道指向の途上国産業コリドー形 成支援による日本の世界貢献，運輸と経済， 74 巻 2 号, pp.112-114, 2014.

9) United Nations: Probabilistic Population Projections based on the World Population Prospects, The 2012 Revision. http://esa.un.org/unpd/ppp/

10) 土井健司，中西仁美，杉山郁夫，柴田久：QoL 概念 に基づく都市インフラ整備の多元的評価手法の開発, 土木学会論文集 D, Vol.62, pp.288-303， 2006.

11) JICA : 都市交通計画策定にかかるプロジェクト研究, JICA レポート, 2011.

12) 伊藤圭, 中村一樹, 加藤博和, 林良嗣 : アジア開発 途上国都市の旅客交通を対象とした低炭素輸送機関 選定手法，環境共生，Vol.24，pp.23-31， 2014.

13) Sanit, P., Nakamura, F., Tanaka, S. and Wang, R.: The role of location choice behavior and urban railway commuting of Bangkok households, Urban and Regional Planning Review, Vol. 1, pp. 1-17, 2014.

14) 藤田将人, 中村一樹, 加藤博和, 林良嗣, 前田翼 : アジア途上国大都市におけるインフラ整備による交
通手段の魅力度改善評価，土木計画学研究・講演集, Vol.47, 2013.

15) 藤田将人, 中村一樹, 加藤博和, 林良嗣, ワスンタ ラースク・ワシニー : タイ・バンコク都における世 代・収入による QOL 価值観の違いに関する研究，第 16 回日本環境共生学会学術大会, 2013.

16) 戸川卓哉, 加藤博和, 林良嗣 : トリプルボトムライ ン指標に基づく小学校区単位の地域持続性評価, 土 木計画学論文集 D3，Vol.68，pp.I_383-396， 2012.

17) 藤森真一郎, 増井利彦, 松岡譲 : 世界温室効果ガス の半減シナリオとその含意, 環境システム研究論文 集, Vol.39, No.2, pp.243-254, 2011.

18) Nakamura, K., Hayashi, Y. and Kato, H.: Low-carbon land-use transport to improve liveability of Asian developing cities, The Selected Proceedings of the 13th WCTR, 2013.

19) 中村英夫, 林良嗣, 宮本和明 : 広域都市圈土地利用 交通分析システム，土木学会論文集，第 335 号, pp.141-153, 1983.

20) Schneider, R. J.: Theory of routine mode choice decisions; an operational framework to increase sustainable transportation, Transport Policy, Vol. 25, pp. 128-137, 2013.

21) OTP Thailand: Executive summary: Transport Dada and Model Center v (TDMC v), OTP, Bangkok, 2007.

22) 林良嗣, 富田安夫：マイクロシミュレーションとラ ンダム効用理論を応用した世帯のライフサイクル-住 宅立地一人口構成予測モデル，土木学会論文集，第 395 号, pp.85-94, 1988.

23) The World Bank: Thailand: Making Transport More Energy Efficient, 2009.

24) The World Bank: Strategic Urban Transport Policy Directions for Bangkok, 2007.

25) Office of Transport and Traffic Policy and Planning: Mass Rapid Transit Master Plan in Bangkok Metropolitan Region, M-Map, 2010.

26) Hayashi, Y., Mai, X. and Kato, H.: The Role of Rail Transport for Sustainable Urban Transport, In Rothengatter, W., Hayashi, Y. and Schade, W. (Eds.) Transport Moving to Climate Intelligence, Springer, New York, 2011.

(2015. 2. 27 受付)

\title{
THE METHODOLOGY OF DIAGNOSIS AND TREATMENT FOR LOW-CARBON TRANSPORT DEVELOPMENT USING QOL ANALYSIS IN ASIAN DEVELOPING MEGACITIES
}

\author{
Kazuki NAKAMURA, Yoshitsugu HAYASHI, Fumihiko NAKAMURA, \\ Atsushi FUKUDA and Kumiko NAKAMICHI
}

It is a globally important challenge for low-carbon transport development in Asian developing countries to secure multiple benefits. However, there are limitations in applying conventional forecasting analysis to it under rapidly-changing socioeconomic situations. This study is aimed at developing the methodology of designing long-term measures with the AVOID, SHIFT, IMPROVE strategies for low-carbon transport systems in Asian developing megacities in 2050, by introducing QOL (Quality of Life) analysis. It consists of diagnosis and treatment for the low-carbon transport development. 